\title{
Flood Analysis at Ramghat, Pokhara, Nepal Using HEC-RAS
}

\author{
Keshav Basnet* and Deepak Acharya \\ Infrastructure Engineering and Management Program \\ Department of Civil and Geomatics Engineering \\ Pashchimanchal Campus, Institute of Engineering \\ Tribhuban University, Nepal \\ *Email: basnet.keshav@wrc.edu.np
}

\begin{abstract}
Flooding in Ramghat area of Pokhara, Nepal is the major problem that has to be faced every year by the people residing nearby the area. Main goal of this study was to conduct the flood analysis of Seti River in Ramghat. Catchment area of the Ramghat was calculated to be $574.56 \mathrm{sq}$. km. using ArcGIS where the area above $5000 \mathrm{~m}$ elevation was $52 \mathrm{sq} . \mathrm{km}$. and area below $3000 \mathrm{~m}$ elevation was 356 sq. km. Precipitation data of two meteorological stations, Pokhara airport and Lumle, were used in this research for the calculation of peak discharge. PCJ method (1996) was used to estimate the peak flood and also compared with the peak flood calculated using Modified Dicken's formula, WECS/DHM method, Rational method and Sharma and Adhikari (2004) method. Peak flood values were found to be $1918 \mathrm{~m}^{3} / \mathrm{s}$ and $2336 \mathrm{~m}^{3} / \mathrm{s}$ by PCJ method for return period of 50 years and 100 years respectively. The HEC-RAS modelling was performed for these flooding situations to determine the water surface profile along the eight cross-sections of the Ramghat. Finally, the floodplain map was prepared using the topographic map and the Google Earth Map. It was found that 50 years flood in Ramghat could inundate three cemetery shades situated along the river banks. Most importantly, 100 years' peak flood was found more vulnerable for residential buildings too. The flood plain maps prepared in this study can be used by government authorities for planning, decision making, early warning system and disaster risk management. Additionally, the rating curve was prepared for the outlet section of Ramghat that can be used to estimate the river discharge during flooding in future.
\end{abstract}

Keywords: River flooding; Hydrologic analysis; Peak flood; Hydraulic modelling; Floodplain map

\section{Introduction}

Mean monsoon precipitation pattern over the Nepal can be seen in Figure 1. Kaski is the area of high intensity of rainfall throughout the year in
Nepal. About $80 \%$ of rainfall normally occurs in four months, June, July, August and September. The mean monsoon precipitation around the Pokhara is $3500 \mathrm{~mm}$ to $4500 \mathrm{~mm}$ (Draft Report, 
2015). Area of high intensity rainfall and steep slopes in upstream sides of the river makes it response rapidly for the peak discharge. Also, urbanization of the area in catchment is reducing the infiltration capacity of the soil, increase discharge in downstream. The large area of catchment has been taken by Seti River at a drainage point in Pokhara. Seti River flows through the deep and narrow gorges in Pokhara City. In Ramghat, Seti River enters through a narrow gorge and exits through similar narrow gorge. This Seti River basin drainage point in Ramghat has catchment area about 574.5 sq. km. In Ramghat of Pokhara, it makes the large plain area which has been bounded by the higher level of land around, where it enters through a narrow gorge and leaves through the similar narrow outlet gorge to downstream (Figure 2). Ramghat area gets flooded every year. Figure 3 shows the after flooding condition of Ramghat area. The narrow outlet of the Seti River is main cause of every year's flood over the Ramghat area. A proper analysis of the river morphology, characteristics and hydrology shall be useful in decision making process for the flood prediction and flood control practice and soil loss. The main objective of this study was to analyze flooding in Ramghat area, Pokhara. The HECRAS was used for hydraulic modelling for 50 and 100 years return period.

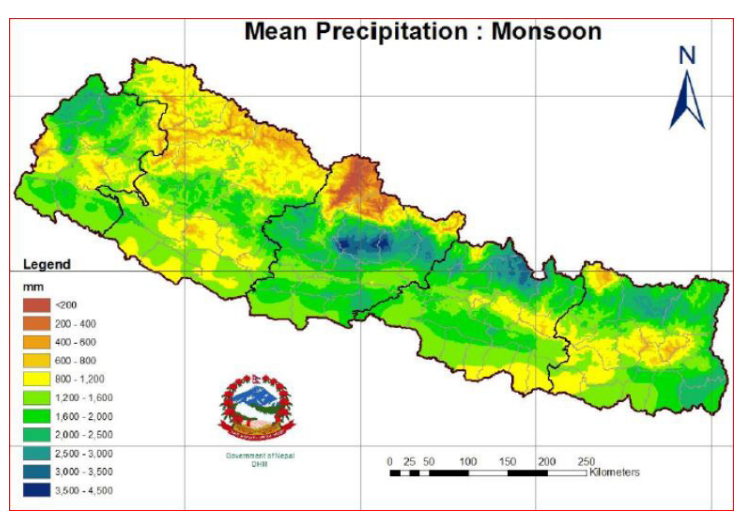

Figure 1: Mean monsoon precipitation in Nepal (Source: Draft Report, 2015)

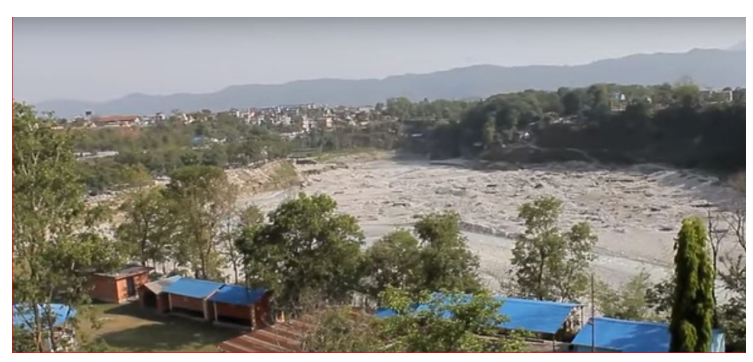

Figure 2: Before Flooding Condition of Ramghat area (Source: Bhupal Creation, YouTube)

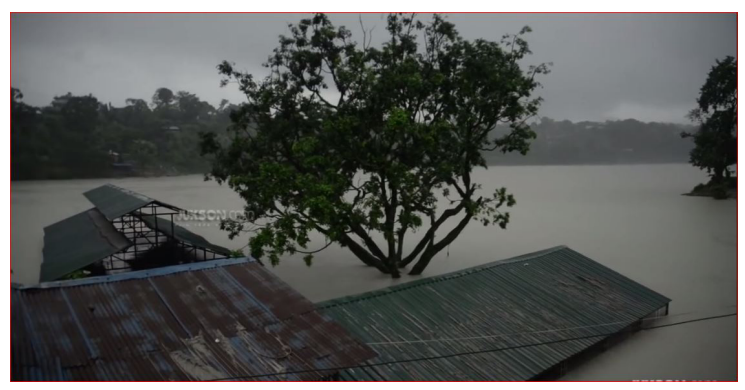

Figure 3: After flooding condition of Ramghat area (Source: Bhupal Creation, YouTube)

\section{Material and Methods}

\subsection{Catchment Area Calculation}

The study area lies between the $28^{\circ} 12^{\prime} 40^{\prime \prime}$ to $28^{\circ} 35^{\prime} 16^{\prime \prime}$ North to $83^{\circ} 48^{\prime} 36^{\prime \prime}$ to $84^{\circ} 03^{\prime} 59^{\prime \prime}$ to the East. The elevation ranges from $800 \mathrm{amsl}$ to 7000 amsl. Total catchment area was divided 
to area below $5000 \mathrm{~m}$ elevation and above $5000 \mathrm{~m}$ elevation. The catchment area required for the hydrological analysis was calculated by the using the $30 \mathrm{~m}$ resolution DEM in ArcGIS as shown in Figure 4. The Catchment area was obtained to be 574.5 sq. km., under which, the catchment area over the $5000 \mathrm{~m}$ elevation was calculated $52 \mathrm{sq}$. $\mathrm{km}$. and below $3000 \mathrm{~m}$ elevation was calculated to be $356 \mathrm{sq}$. $\mathrm{km}$. The total area determined using ArcGIS was observed to be comparable with the area calculated using Google Earth Map.

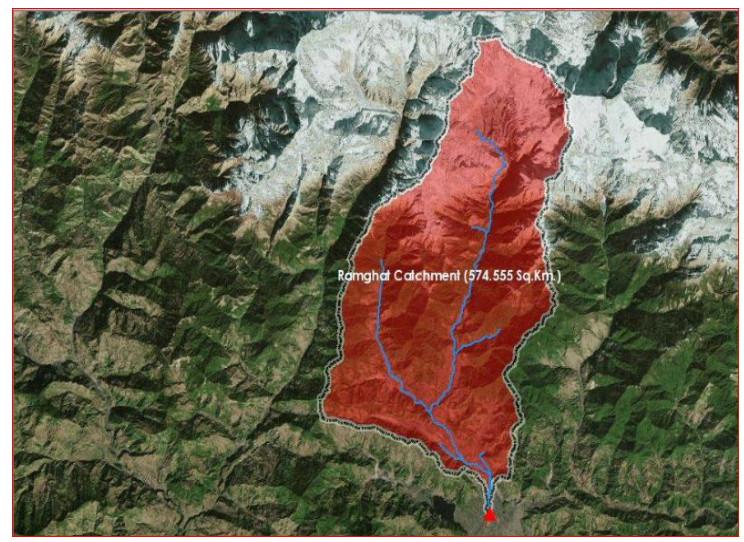

Figure 4: Catchment area calculation using ArcGIS

\subsection{Hydrologic Analysis}

The flood discharge calculation is an important part for designing hydraulic structures and river training works. Hydrological analysis for the river basin is important factor to determine the peak flood. Hydrologic analysis was conducted in this study for designing peak flood for 50 and 100 years return period. Jha (1996) performed hydrological analysis and developed PCJ method to estimate peak flood for any catchment drain outlet in Nepal with major input variables of rainfall intensity and catchment area. Rijal (2014) found that the PCJ Method (1996) was comparable with only 5\% deviation for East Rapti River Basin with frequency analysis (Gumbel method) of gauged flow from 43 years' data set of Rajaiya station (DHM station no. 460) among the Rational method, PCJ (1996) method, Modified Dicken's method, SCS method, Sharma and Adhikari (2004) method, WECS/ DHM (1990) method and Tahal et al. method. A hydrological analysis for design discharge for hydropower, the catchment area ratio method was found to be suitable (Basnet et al., 2018).

\subsection{PCJ Method (1996)}

The PCJ method (Jha, 1996) calculates design peak flood discharge based on hourly rainfall intensity. This method employs following formula.

$Q_{p}=16.67 a_{p} O_{p} \Phi F k_{f}+Q$

Where,

$Q_{p}=$ Maximum rainfall design discharge for required exceedence probability in $\mathrm{m} / \mathrm{s}$

$a_{p}=$ Maximum rainfall design intensity for required exceedence probability in $\mathrm{mm} /$ $\min$

$O_{p}=$ Infiltration coefficient of the basin, derived as the function of exceedence probability

$\Phi=$ Areal reduction coefficient of maximum rainfall discharge that depends on the catchment size

$F=$ Catchment area of drainage basin in sq. $\mathrm{km}$.

$k_{f}=$ Coefficient for unequal distribution of 
rainfall in different size of basin, captured by one rain

$Q_{s}=$ Discharge by melting of snow, can be taken as 0 to $10 \%$ of $Q_{P}$ in the absence of data

$\mathrm{a}_{\mathrm{p}}=\mathrm{a}_{\mathrm{hr}} \cdot \mathrm{k}_{\mathrm{t}}$

$\mathrm{Q}_{50}=\exp ^{3\left[\ln \mathrm{Q}_{2}+2.054\left(\frac{\ln \left(\frac{Q_{100}}{Q_{2}}\right)}{2.326}\right]\right.}$

Where, $\mathrm{Q}_{2}, \mathrm{Q}_{50}$ and $\mathrm{Q}_{100}$ are 2, 50 and 100 years return period floods respectively and $\mathrm{A}_{3000}$ is the catchment area under $3000 \mathrm{~m}$ elevation.

where, $a_{t r}=$ Hourly rainfall intensity for required exceedence probability at selected rainfall stations in $\mathrm{mm} / \mathrm{min}$

$k_{t}=$ Reduction coefficient of hourly rainfall intensity that depends on the catchment size

\subsection{Rational Method}

Rational method is used for small catchment area for flood calculation because the time of concentration for small catchment is small (Basnet and Neupane, 2018). This assumes the time of concentration is equal to the rainfall duration. This is given by following equation.

$Q=\frac{C\left(I_{t(c, p)}\right) A}{360}$

Where, $\mathrm{Q}=$ Peak flood discharge in $\mathrm{m}^{3} / \mathrm{s}, \mathrm{C}$ $=$ Runoff coefficient, $\mathrm{A}=$ Catchment area in hectare and $\mathrm{I}_{\mathrm{t}(\mathrm{c}, \mathrm{p})}=$ Intensity of rainfall in $\mathrm{mm} /$ $\mathrm{hr}$ at time of concentration $\mathrm{t}_{\mathrm{c}}$ and probability of exceedence $\mathrm{p}$.

\subsection{WECS/DHM (Hydest) Method}

WECS/DHM (1990) method employs regional prediction methods. It is a modification of WECS (Water and Energy Commission Secretariat) approach of 1982 and has been developed jointly by WECS and DHM. Following equations were used for flood forecasting.

$\mathrm{Q}_{2}=1.8767\left(\mathrm{~A}_{3000}\right)^{0.8783}$

$\mathrm{Q}_{100}=14.639\left(\mathrm{~A}_{3000}\right)^{0.7342}$ 
2.8. Comparison of Peak Flood by PCJ Method with Other Methods

In this research, the peak flood was determined by the PCJ method (1996) and compared with other methods: WECS/DHM, Sharma and Adhikari (2004), Rational method and modified Dicken's formula. Meteorological station at Pokhara airport (index no.: 804) was selected for flood calculation first. Table 1 shows the calculation of the peak flood by PCJ method for five different return periods $(10,33,50,100$ and 300 years) using the data set of Pokhara airport station. Then, a comparison with the equal weight of the rainfall intensity was made with the Lumle meteorological station (index no: 812) as shown in Table 2. The designed peak flood for the five different return periods have been graphically illustrated in Figure 5. There was no significant difference in flood discharge up to the 33 years return period if one used the rainfall data from Pokhara airport station or Lumle station. However the difference increased linearly beyond the 33 years return period such that the difference reached about $300 \mathrm{~m}^{3} / \mathrm{s}$ for 100 years return period. Though the effects of station location was observed here, the rainfall data from Pokhara airport was taken for the peak flood calculation using PCJ method since the station is much closed to the study area compared to the Lumle station. The calculated peak flood values by PCJ method with the 100 years return period was also compared with other methods mentioned above.
Table 1: Peak floods calculation using PCJ method

\begin{tabular}{|c|c|c|c|c|c|}
\hline \multirow{2}{*}{$\begin{array}{c}\text { Rainfall station } \\
\text { 804 at Pokhara } \\
\text { airport }\end{array}$} & \multicolumn{5}{|c|}{ Return period in years } \\
\cline { 2 - 6 } & 10 & 33 & 50 & 100 & 300 \\
\cline { 2 - 6 } & 1.34 & 1.94 & 2.17 & 2.50 & 301.00 \\
\hline Parameters & & & & & \\
\hline Kt & 0.84 & 0.84 & 0.84 & 0.84 & 0.84 \\
\hline ap & 1.26 & 1.63 & 1.79 & 1.95 & 2.23 \\
\hline Op & 0.5 & 0.75 & 0.85 & 0.95 & 1.0 \\
\hline$\Phi$ & 0.146 & 0.146 & 0.146 & 0.146 & 0.146 \\
\hline Kf & 0.992 & 0.992 & 0.992 & 0.992 & 0.992 \\
\hline $\mathrm{F}$ & 522.5 & 522.5 & 522.5 & 522.5 & 522.5 \\
\hline Q (m $\left.{ }^{3 / s}\right)$ & 793 & 1541 & 1918 & 2336 & 2810 \\
\hline
\end{tabular}

Similarly, comparison of peak flood estimated from data set of two different stations have been shown in table as well as graph below.

Table 2: Comparison of peak floods estimated from data set of two different stations

\begin{tabular}{|c|c|c|c|}
\hline \multirow[b]{2}{*}{$\begin{array}{l}\text { Return } \\
\text { Period } \\
\text { (years) }\end{array}$} & \multicolumn{3}{|c|}{ Discharge $\left(\mathrm{m}^{3} / \mathrm{s}\right)$} \\
\hline & $\begin{array}{c}\text { Pokhara airport } \\
\text { station }\end{array}$ & $\begin{array}{l}\text { Lumle } \\
\text { station }\end{array}$ & $\begin{array}{c}\text { Average } \\
\text { of Pokhara } \\
\text { airport } \\
\text { station } \\
\text { and Lumle } \\
\text { station }\end{array}$ \\
\hline 10 & 793 & 841 & 817 \\
\hline 33 & 1541 & 1477 & 1509 \\
\hline 50 & 1918 & 1773 & 1846 \\
\hline 100 & 2336 & 2083 & 2209 \\
\hline 300 & 2810 & 2427 & 2618 \\
\hline
\end{tabular}




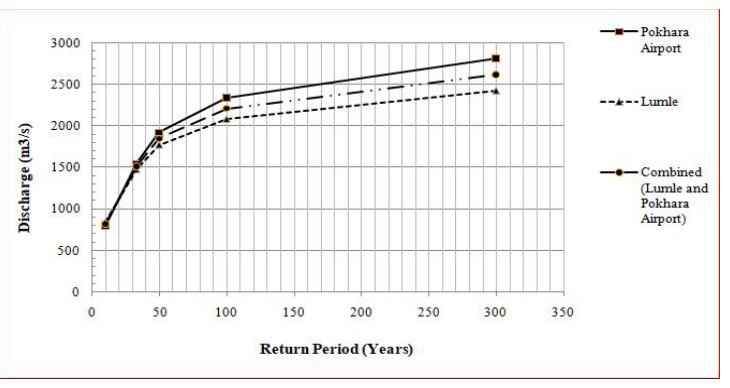

Figure 5: Comparison of design peak flood from data set of two different stations

\subsection{River Topography and Bathymetry Data Collection}

Total eight cross-sections were taken in variable distance as shown in Figure 6 where the total distance between two ends cross sections was $754 \mathrm{~m}$. The level survey was conducted for the topographic data collection of the flood plain as shown in Figure 7.c. The mouth and tail of the study area were complicated such that the inlet and outlet portions of the river were not accessible for the direct measurement across the cross-sections. Hence, these were calculated from the photograph and using the measurement from the known dimension of the object in an image that had approximately equal distance from the point of photograph taken. For an idea of photographic survey used in this study, one can see Figure 8 where the photographic survey of inlet portion has been shown as an example.

The flow was very high during the measurement such that bathymetry of river flowing channel could not be measured (see Figures 7.a and 7.b). One discharge was measured in flanged section by current meter on 29 June, 2018. The measured discharge $138.53 \mathrm{~m}^{3} / \mathrm{s}$ was used to estimate the depth of the flow in respective section knowing the width of the section, slope of the channel and top Manning's roughness coefficient assuming the rectangular section. This made the higher depth in constricted section and low depth in flanged section for equivalent depth. It indicated the bed slope different from the real slope. On the other hand, it results the different patterns of water surface profile with bed slope. However for the purpose of flood prediction, a large flow area will be above the water level during the measurement that was used as input for the HEC-RAS modelling, the error of such depth was expected to be negligible.

Data taken from the field survey were linked with the elevation from Google Earth. The twenty-meter contour interval topographic map in Google Earth and similar map that was provided by the Survey Department of Nepal was used to verify the area and elevation.

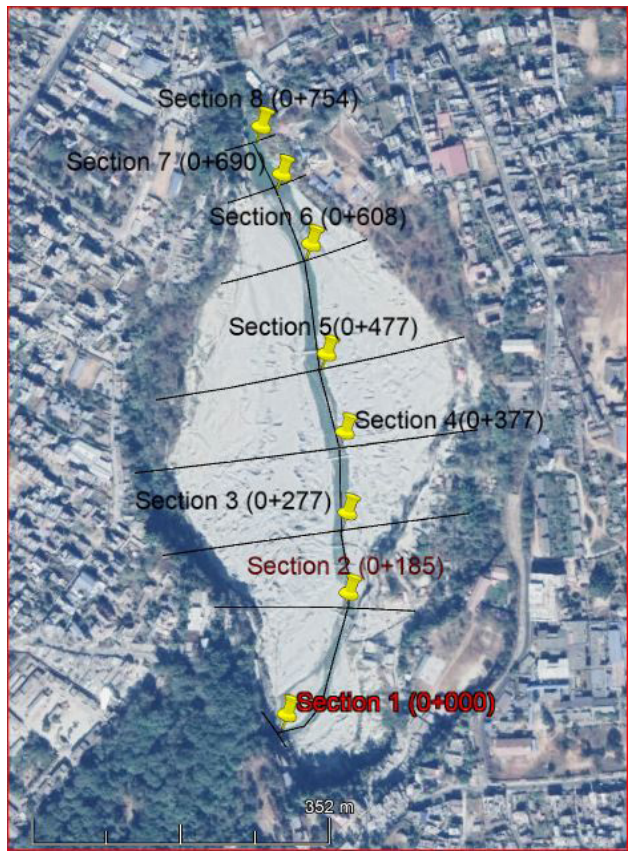

Figure 6: Layout of the eight cross-sections presented on the top of Google Earth Map 
a)

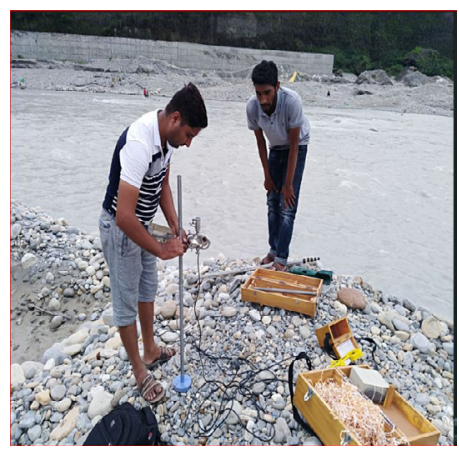

b)

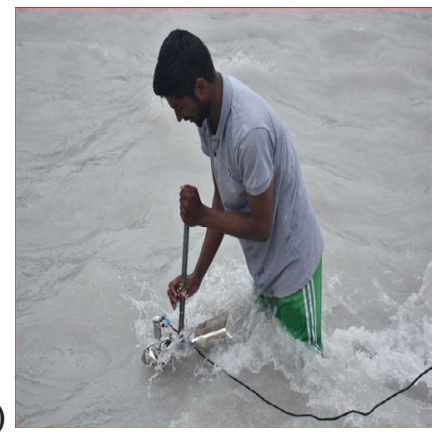

c)

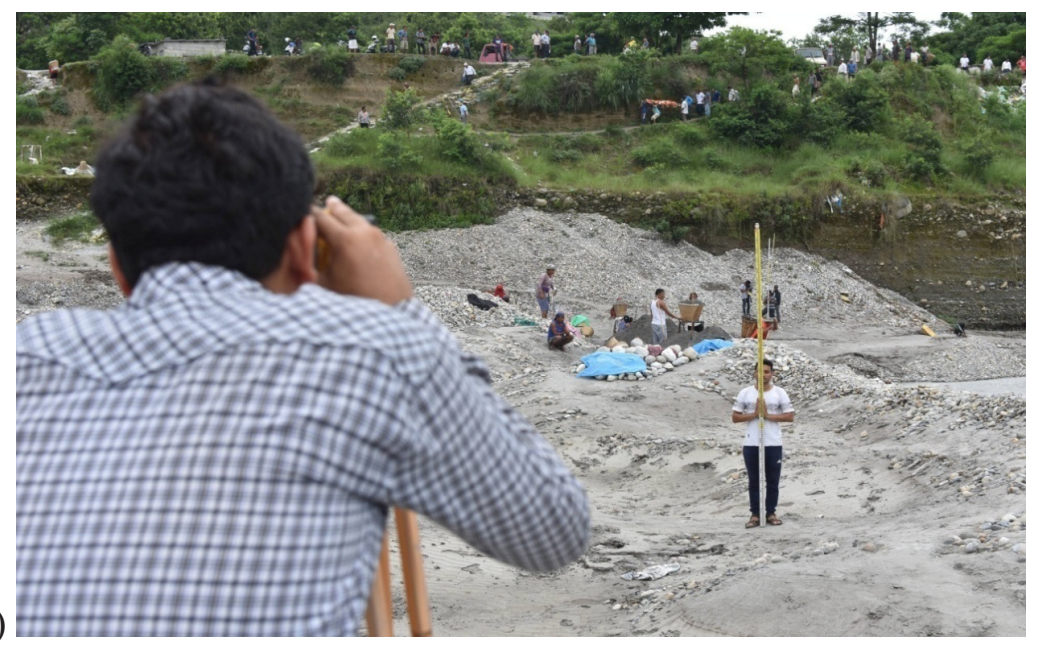

Figure 7: Field measurements; a) Preparation of current meter; b) Velocity measurement using current meter; c) Survey for cross-section data

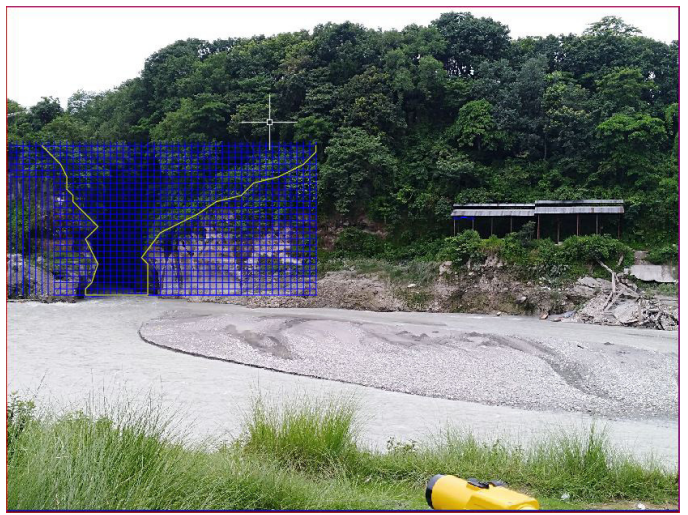

Figure 8: The Photographic method used to estimate the inaccessible section

\subsection{Velocity Measurement and Estimation of Flow Depth}

Only the data over the water level was taken for cross-section data and the section of the water flowing channel was estimated analytically assuming rectangular section from known discharge, flow width and average slope. It was because of inability in direct measurement of cross-sections as explained in section 2.3. Rectangular section is easy for calculation to find equivalent depth where only the top width of flow was known. There are various techniques to determine the velocity of river flow. Some techniques (e.g., propeller current meters and Acoustic Doppler Velocimeter) required placing the instrument in the flow, which can pose practical problems such as access and local 


\section{Nepal Engineers' Association, Gandaki}

effect on the flow. Additionally, such methods can measure velocity at a single point only at a time. Some other techniques, such as Particle Image Velocimetry, can give images of velocity fields, but are not practical to use for large area of river flow (Basnet, 2010). Flow velocity was measured in the field by using current meter as shown in Figure 7.b. Discharge of water flowing through a section can be determined using Manning's equation. Basnet and Neupane (2018) developed a methodology to estimate the size of drains for the stormwater drainage system of Lamachaur, Pokhara, Nepal using Manning's equation. The methodology presented by them was used in this study to determine the flow depth. Manning's formula is given by,

$Q=\frac{1}{n} A R^{\frac{2}{3}} S^{\frac{1}{2}}$

Where,

$Q=$ Discharge through the Section $\left(\mathrm{m}^{3} / \mathrm{s}\right)$

$n=$ manning's roughness coefficient

$A=$ Flow area $\left(\mathrm{m}^{2}\right)$

$R=$ Hydraulic mean radius $(A / P)$

$P=$ Wetted perimeter $(\mathrm{m})$

$S=$ Bed slope of the river channel

\subsection{Modelling by HEC-RAS}

The Hydrologic Engineering Centre - River Analysis System (HEC-RAS) developed by U.S. Army Corps of Engineers can be used to analyze the river with the input of river hydraulic properties. It is free modelling software for the modelling of the flood in one dimensional flow. It was tested in different part of the world and has been found appropriate for floodplain prediction (Horritt and Bates,
2002). The HEC-RAS needs the peak flood, river bathometry, channel slope, topography of the area, manning's roughness coefficient as the input of the modelling. Flood hazard mapping and vulnerability assessment has been practiced in Nepal. Similarly, Dangol and Bormudoi (2015) used HEC-RAS for flood hazard mapping and vulnerability analysis of Bishnumati River in Kathmandu, Nepal. However, the freely available $30 \mathrm{~m}$ resolution DEM data is not sufficient for the prediction of precise flood level and for effective early warning system. Hence, a high resolution DEM data is always an important factor for modelling for small catchments (Dangol and Bormudoi, 2015).

The cross-sections of the different locations were prepared, referred as geometric data for the HEC-RAS model preparation. The HECRAS model was prepared with the length of downstream section from the previous section, cross-sectional data, Manning's roughness coefficient for the main stream, right over bank and left over bank for sub-critical flow. The Manning's roughness coefficient was taken 0.04 for the main water flowing channel and 0.065 for right over bank and left over bank portion of the river containing cobbles and boulders respectively (Phillips and Tadayon, 2007). The contraction coefficient and expansion coefficient were considered as 0.1 and 0.3 respectively for gradual transition (Reference Manual, 2002). 


\section{Results and Discussions}

\subsection{Peak Flood}

For the comparison of the peak flood, the 100 years return period peak flood calculated using different methods for same outlet of the catchment has been presented in Table 3. Rijal (2014) found that the Rational method over estimated and WECS/DHM (Hydest) method, Sharma and Adhikari (2004) method, Tahal et al. (2000) method and modified Dicken's method underestimated flood for East Rapti River Basin and the author concluded the PCJ method (1996) was most comparable with the gauge station data. Therefore, the PCJ Method (1996) was preferred in the study to calculate peak flood for 50 years and 100 years return period. Similar comparison analysis can be made in this study as the one made by Rijal (2014). As one observed in Table 3, Rational method over estimated the discharge and WECS/DHM method, Sharma and Adhikari method and modified Dicken's method under estimated the discharge compared to the peak discharge by PCJ method.

The 50 years return period flood estimation is necessary for river training and bank protection structures such as spurs and gabion protection works. The 100 years return period flood estimation is necessary for the intermediate important structures. The 100-yr peak flood is used generally for flood plain development, medium-sized flood protection works, and regional urban drainage facilities. For places where probable maximum precipitation (PMP) has not been developed, where failure of river protection or hydraulic structures keeps human life in risk will be designed with the flood more than 100 years return period (Ponce, 2008).

Table 3: Comparison of peak floods estimated by different methods

\begin{tabular}{|c|l|c|}
\hline \multirow{2}{*}{$\begin{array}{c}\text { S. } \\
\text { No. }\end{array}$} & Methods & $\begin{array}{c}\text { High Flood } \\
\text { Discharge }\left(\mathrm{m}^{3} / \mathrm{s}\right)\end{array}$ \\
\cline { 2 - 3 } & $\begin{array}{l}\text { Modified } \\
\mathrm{T}=100 \text { years }\end{array}$ \\
\hline 2 & Dicken's method & 1481 \\
\hline 3 & WECS/DHM & 1093 \\
\hline & Rational method & 2875 \\
\hline 4 & $\begin{array}{l}\text { Sharma and } \\
\text { Adhikari (2004) } \\
\text { method }\end{array}$ & 1379 \\
\hline 5 & $\begin{array}{l}\text { PCJ Method } \\
(1996)\end{array}$ & 2336 \\
\hline
\end{tabular}

\subsection{River Sections and Profile}

The HEC-RAS model was prepared for 50 and100 years return period with different peak flood discharges. For cross-sections, measurement was made by levelling survey at accessible locations and indirect measurement by photographic method was done for inaccessible locations. Base of each section were assumed rectangular section, because these were estimated analytically due to inability of direct measurement during field survey. The cross section profile of section 7 has been shown in Figure 9 as an example. The HEC-RAS model did not provide access to overhanging section, so was averaged to the rectangular section at lower part of outlet section. Similarly, the inlet section and outlet section were not accessible for direct measurement, these were measured using photographs. The average slope used 
may have overestimated the depth, was not corrected, so bed slope went down at the inlet section and outlet section in modelled profile. Hence, the analysis was performed using other remaining six sections and their flood profiles for different years return period. The water surface profile was determined by hydraulic modelling using HEC-RAS and presented in Figure 10. It was observed that the water surface profile followed the pattern of river bed profile in general. However one can observe the effect of overhanging section with narrow inlet at the mouth of the Ramghat.

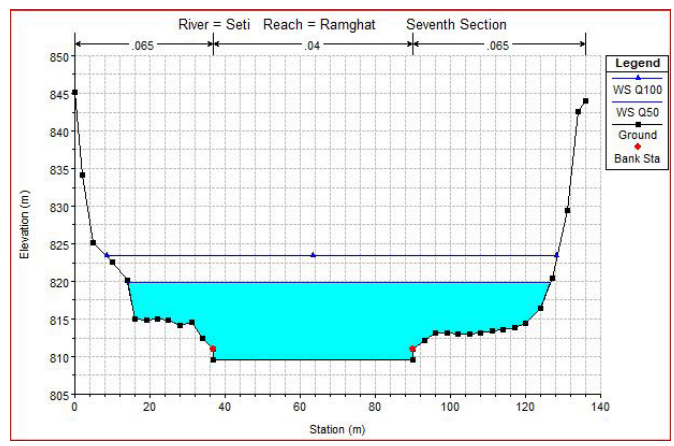

Figure 9: Cross-section plot of section-7 with water surface levels

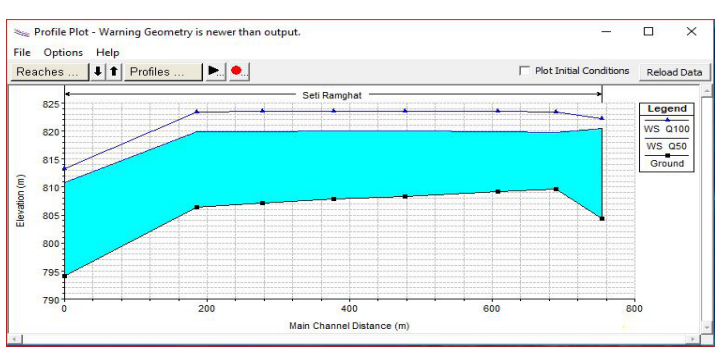

Figure 10: Modelled water surface profile along the Seti River, Ramghat

\subsection{Rating Curve}

The rating curve at the outlet section was estimated by using HEC-RAS, which showed the elevation discharge relationship at that section of the consideration. The rating curve 50 at the outlet section, shown in Figure 11, might be useful as the input for any other hydraulic analysis of the channel beyond that section of the river. The rating curve thus prepared by using HEC-RAS model at outlet section showed the linear relation up to 50 -yr flood $\left(1918 \mathrm{~m}^{3} / \mathrm{s}\right)$ and the curve started deviating beyond that flood discharge. Further investigation about this nature of rating curve can be made in future extension of this study.

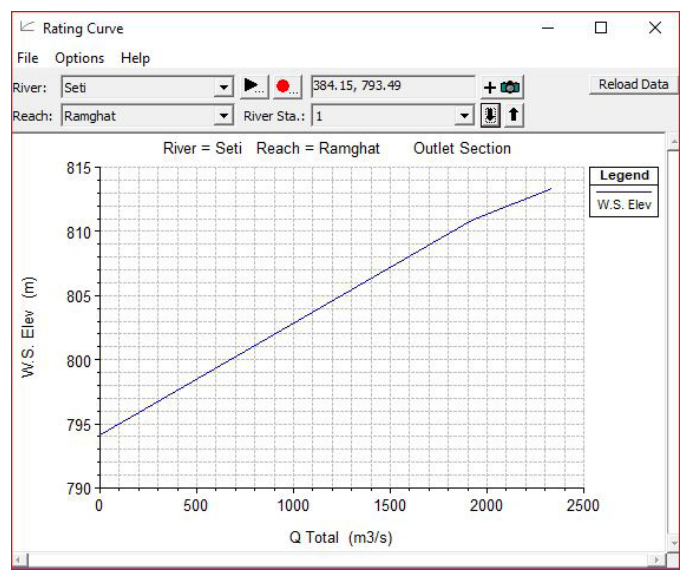

Figure 11: Rating curve at outlet section of Seti River at Ramghat

\subsection{Flood Plain Map}

The modelled profile of the water surface along the sections provided were used to create the flood plain map for 50 years and 100 years floods using topographic map overlaid in Google Earth Map for clear visibility. The contour lines from the topographic map were used for flood plain mapping. The flood plain maps for 50 years and 100 years return period have been presented in Figure 12. The 50 years return period flood was analyzed to be less destructive to the residential building structures. It mentioned to just inundate the existing funeral shades and encroachment of the river banks, whose top is 
rested by residential buildings. The flood plain map prepared for 100 years return period showed that additionally the residential buildings in the South East part of the Ramghat area could be in vulnerable situation by this flood. It showed to inundate the parking lot and some residential shades in lower part of the river bank too. Certainly, the loose soil bank might also be scored by the flood around Ramghat.

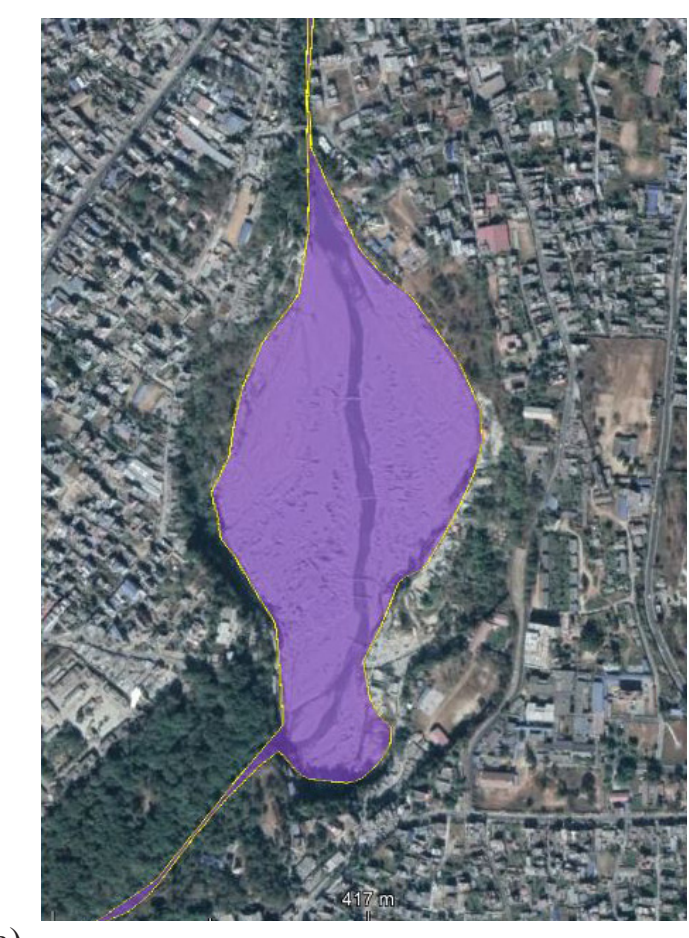

a)

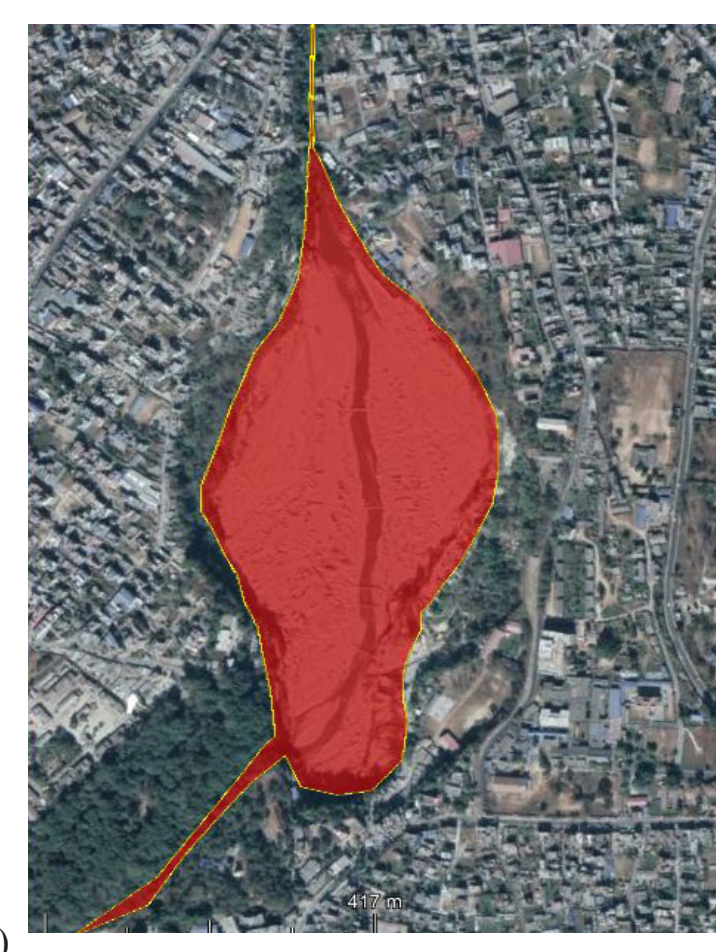

b)

Figure 12: Floodplain maps for different return periods; a) 50 years; b) 100 years

\section{Conclusion}

Main idea of this study was to perform flood analysis along the Seti River at Ramghat, Pokhara, Nepal which is the area facing problem of flooding every year. The peak flood discharges of $1918 \mathrm{~m}^{3} / \mathrm{s}$ and $2336 \mathrm{~m}^{3} / \mathrm{s}$ were calculated for return period of 50 years and 100 years respectively using PCJ method (1996). The flooding level at Ramghat area was estimated for 50 and 100 years return period by hydraulic modelling using HECRAS. Then, flood plain maps were prepared for those two peak floods. It was found that three funeral shades, in Northern and Southern parts of the flanged river section, could be in vulnerable situation by 50 years return period flood. Still, there is continuous encroachment in bank side established with loose soil material; there may be indirect hazard of 50 years flood for residential buildings resting on the top of elevated banks. Similarly, the observation of 100 years flood plain map showed that the highest flood level was estimated up to around $825 \mathrm{~m}$ elevation and spread away more than 


\section{Nepal Engineers' Association, Gandaki}

$200 \mathrm{~m}$ wide from the centreline of the channel. Most importantly, large number of residential buildings and a parking place in South East part of the flanged section could be in vulnerable situation directly by 100 years return period flood. During the field survey, it was observed that many residential buildings are resting over the scoring side bank of the river supported with the loose gravel deposits. This has threatened the residential area to be in more vulnerable condition. Furthermore, the Rating curve was prepared for the Seti River at the Ramghat using HEC-RAS model. The Rating curve performed straight line in initial phase (for discharge up to $1918 \mathrm{~m}^{3} / \mathrm{s}$ ) and slightly started to deviate with a curvilinear shape. The floodplain maps prepared in this study can be used by government authorities for planning and decision making (e.g., to evaluate the recently constructed concrete retaining work at the inlet side of the river reach in Ramghat, to prepare the building by-laws for the Ramghat area and to design other river bank protection structures, river training works etc.). Additionally, it can be used by insurance agencies to determine the insurance cost of vehicles of owners located in the Ramghat area. In conclusion, the methodology developed in this study can be useful for disaster risk management and early warning system.

\section{Acknowledgement}

Authors would like to thank Er. Tulasi Ram Bhattarai, Senior Divisional Engineer, Ministry of Energy, Water Resource and Irrigation, Nepal for providing relevant data. Prof. Dr. Prem Chandra Jha, Institute of Engineering, Tribhuvan 52

University, Nepal provided his model to calculate peak flood. Authors are thankful to him for his kind support regarding peak flood calculation. Authors are also thankful to the MSc students of 2074-076 batch, Infrastructure Engineering and Management Program, Pashchimanchal Campus, Pokhara, Nepal for their support during field measurements. Finally, the authors would like to appreciate Department of Civil and Geomatics Engineering, Pashchimanchal Campus, Pokhara, Nepal for providing the current meter and level machine for the purpose of field measurements.

\section{References}

Basnet, K. (2010). "Large-Scale Particle Image Velocimetry for resolving unsteady flow features at cylinders." M.Sc. Thesis, Department of Civil \& Architectural Engineering, College of Engineering and Applied Science, University of Wyoming, Laramie, Wyoming, USA. December 2010.

Basnet, K., Baniya, U., and Karki, S. (2018). "Comparative study of design discharge calculation approaches: a case study on Padhu Khola, Kaski, Nepal." Oodbodhan: A Journal of TUTA, Pashchimanchal Campus, 5 (5).

Basnet, K. and Neupane M. (2018). "Storm water drainage design based on hydrologic analysis: a case study on Lamachaur catchment area, Pokhara, Nepal." Oodbodhan: A Journal of TUTA, Pashchimanchal Campus, 5 (5).

Dangol, S. and Bormudoi, A. (2015). "Flood hazard mapping and vulnerability analysis of Bishnumati River, Nepal." Nepalese Journal on Geoinformatics, Survey Department, Nepal, 14, 20-24. 
Draft Report (2015). "Study of climate and climatic variation over Nepal." Draft Report, Department of Hydrology and Meteorology, Ministry of Science, Technology and Environment, Government of Nepal.

Reference Manual (2002). "HEC-RAS River Analysis System." Hydraulic Reference Manual, Version 3.1, US Army Corps of Engineers, Hydrologic Engineering Center, USA. November 2002.

Horritt, M. S. and Bates, P. D. (2002). "Evaluation of 1D and 2D numerical models for predicting river flood inundation." Journal of Hydrology, 268 (1-4), 87-99.

Jha, P. C. (1996). "Maximum rainfall discharge for the design of road structures of Nepal." Technical University, Moscow, Russia.
Phillips, J. V. and Tadayon, S. (2007). "Selection of Manning's roughness coefficient for natural and constructed vegetated and non-vegetated channels, and vegetation maintenance plan guidelines for vegetated channels in Central Arizona." Scientific Investigation Report 2006-5108, U.S. Department of the Interior, U.S. Geological Survey. Reston, Virginia.

Ponce, V. (2008). "What is the return period of 100 years?" https://ponce.sdsu.edu. Retrieved on July 21, 2018.

Rijal, K. P. (2014). "Comparative study of flood calculation approaches, a case study of East Rapti River Basin, Nepal." Hydro Nepal: Journal of Water, Energy and Environment, $15,60-64$. 